\title{
The Huguenots of South Africa in documents and commemoration
}

\begin{abstract}
This article is about the image of the Huguenots of South Africa that we find in documents and how they were commemorated in South Africa. The article proposes inter alia to investigate when the first anniversary of the Huguenots in South Africa occurred and when the name "Huguenot" gained acceptance in South Africa. It also tries to answer the question what the real contribution of the Huguenots to South Africa was. This is done against the background of the statement that Afrikaans speaking people merely created the "myth" of the Huguenots for their own identity, notably in 1994 after losing the leadership in the government of the country. The article shows that the contribution of the Huguenots to South Africa and its people is much more comprehensive and material.
\end{abstract}

\section{ABSTRAK}

\section{Die Hugenote van Suid-Afrika -'n beeld vanuit dokumente en herdenking}

Hierdie artikel is oor die beeld van die Hugenote van Suid-Afrika wat ons in dokumente vind en oor hoe hulle in Suid-Afrika gedenk is. Die artikel stel ondermeer ondersoek in na wanneer die eerste herdenking van die Hugenote in Suid-Afrika plaasgevind het en ook wanneer die naam "Hugenoot" inslag gevind het in SuidAfrika. Daar word ook probeer om die vraag te beantwoord wat die wesenlike bydrae van die Hugenote tot Suid-Afrika was. Die ondersoek word gedoen teen die agtergrond van die stelling dat die Afrikaners eintlik maar net die "mite" van die Hugenote geskep het om hulle eie identiteit te versterk, veral nadat hulle in 1994 hulle leierskap in die regering van die land verloor het. Die artikel toon aan dat die bydrae van die Hugenote tot Suid-Afrika en al sy mense baie meer omvattend en wesenlik is.

\section{INTRODUCTION}

In 2003 Philippe Denis closes his article The Cape Huguenots and Their Legacy in Apartheid South Africa with the following words "South Africa has now entered another era. The Afrikaner people, who developed the Huguenot myth as a way of strengthening their identity, have lost their leading position in the government of the country. This new situation creates the conditions for a more critical appraisal of the role of the Huguenots in South African history." ${ }^{1}$ Apparently Denis sees the claims of the Afrikaner people to a Huguenot heritage as a "Huguenot

1 Denis Philip, The Cape Huguenots and Their Legacy in Apartheid South Africa. In: Bertrand Van Ruymbeke and Randy J Sparks eds., Memory and Identity. The Huguenots in France and the Atlantic Diaspora. Columbia, University of South Carolina Press. Columbia., 2003, p. 303. 
myth" which Afrikaners invented as a way to strengthen their own identity and now that they have lost their leading position in government it opens the way for a more critical appraisal of the role of the Huguenots in history. This view in a sense echo's the idea of an reconstructed memory as far as the Huguenots of South Africa are concerned. Was it later generations of intellectual and community leaders with connections to the larger national and international scene, influenced by works of history that gave the Huguenots of South Africa the positive identity of brave champions of freedom of conscience and freedom of religion and was this later used by Afrikaner nationalism to strengthen it's own identity. To really answer this question it is necessary to look at how the Huguenots of South Africa are remembered and commemorated.

\section{EARLY DOCUMENTS 1685-1703}

The refreshment post at the southern tip of Africa was started by the Dutch East Indian Company in 1652. At the head of the settlement there was the Political Council with the Commander, later the Governor, at its head. The Political Council under the leadership of the governor as representatives of the Lords XVII of the Dutch East Indian Council controlled the whole of life at the Cape of Good Hope - they were the de jure government that decided on everything from agriculture to religion. They protected the Reformed religion at the Cape but also very effectively controlled it, a system which would continue under the British rule from 1806 and later also in effect under the rule of the National Party up until 1994. From 1652 until 1795 it was the Political Council at the Cape that decided which denominations would be allowed in the Colony, where and when local congregations would be established, which minister would serve where, and who would serve as elders and deacons. Because of their refusal the normal reformed church assemblies of presbyteries and synods were not established at all at the Cape during the reign of the Dutch East Indian Company. It was their explicit policy that the French language must not be spoken at the Cape which would eventually lead to the virtual disappearance of that language at the Cape and that the French congregation effectively became part of the Dutch Reformed Church after the departure of the first and only Refugee minister at the Cape in 1701.

In the early documents about the French destined for the Cape we read the following about how they were identified. On 3 October 1685 the Lords VXII in the Netherlands decided to send more colonists to the Cape and then we read the following "Amongst the aforementioned colonist there may be French Refugees of the Reformed religion ..."2 On 6 October 1687 the Lords XVII reaffirms their resolution of 3 October 1685 and again refers to the "French Refugees" as possible colonists at the Cape, this time together with "Piemontoisen" ${ }^{3}$. In the end nothing came of the scheme to also settle "Piemontoisen" at the Cape.

In the reflections on the rules under which the French Refugees went to the Cape there is also a section under the title "Premier projet d'Etablissement". In the first article of this section it is said that everybody that applied to go to the Cape of Good Hope had to be of the Reformed faith, refugees from France or the valleys of Piedmont. For this they would be examined by commissioners, after which they had to swear the oath of 20 October 1687. To this is added that it is very important for the Company to take only obedient and peace loving subjects to the Cape. Most of the French are of this quality. However it is also known that it took courage, guts and a love of freedom from them apart from the reasons of conscience to surpass all the difficulties that came their way. All these qualities are usually part of people with a lively and impatient nature. It would therefore not be a surprise if there were those among the French who

2 Rijks Archief 's Gravenhage (The Hague), Koloniale Archief 258, Resolutien Here XVII, 3 Oktober 1685.

3 Rijks Archief, 's Gravenhage (The Hauge), Koloniale Archief 259, Resolutien Here XVII, 6 Oktober 1687. 
would not have the necessary flexibility of character. Note must also be taken of the provinces (in France) where they came from since the inhabitants of some are much more obedient than others. ${ }^{4}$ Under the date 16 November 1687 the Lords XVII informs the Cape that French and Piemontoise Refugees will be coming to the Cape and once again it is confirmed that they are all of the reformed religion and for the exercise of their religion a minister will accompany them. ${ }^{5}$ On 19 December 1687 the Chamber of Delft forwards the names of people who will be coming to the Cape on the ship Voorschooten - people who as a result of "the persecution of the true Reformed Religion in France" have come to the Netherlands. In the same letter the names of the passengers on board the Oosterland are also identified as "French Reformed Refugees" 6 Problems with the French at the Cape arose during 1688 and 1689 when they twice asked to be resettled on other land than that given to them and also asked for an own French congregation. When the matter came up in the meeting of the Political Council in the Cape on 28 November 1689, the Commander, Simon van der Stel said that he was worried and experienced many difficulties from some of the "so called refugees", who left France under the pretence of religious persecution by their King. They settled in the Netherlands, where they lived an idle and lazy life under the pretence of being devotees, members and supporters of the Protestant faith. In the end the Council decided to reign in the French impertinences, stop all conspiracies in time by giving them a thorough rebuke and to reprimand them seriously to do their duty. They were also seriously warned to keep to the conditions of the contract under which they came to the Cape and to refrain in future from troubling the Commander with such impertinent requests and to be satisfied with the Church Council of the Stellenbosch Church. ${ }^{7}$ In the meantime Rev Simond had also written a letter with the same request to the Lords XVII. ${ }^{8}$ His request to the Lord XVII was granted ${ }^{9}$ so that in 1691 a third congregation in South Africa was established - the French speaking Drakenstein congregation. By 1691 The Governor, Simon van der Stel, states it clearly that he does not want any more French at the Cape ${ }^{10}$. This is again repeated in a letter from him on 2 July $1699^{11}$ which leads to the decision of the Lords XVII on 22 June 1700 in which they decided that they wanted colonists of the reformed or Lutheran faith at the Cape "but no French". ${ }^{12}$ When handing over the power in the colony to his son Willem Adriaan van der Stel on 30 March 1699 Simon van der Stel warned him that of all the population groups at the Cape the French were the least to be trusted. ${ }^{13}$

Through a deliberate policy of the Governor and the Political Council the use of French at the Cape was smothered so that by 1723 we read that there was only 25 or 26 elderly French left, who still spoke French ${ }^{14}$. Through this policy the Drakenstein congregation was fully incorporated into the Dutch Reformed Church with Dutch as its official language.

4 Reflexions, Premier Projet d'Etablissement. In: C Spoelstra, 1907. Bouwstoffen voor de Geschiedenis der Nederduitsch-Gereformeerde Kerken in Zuid-Afrika. Part 2. Hollands-Afrikaansche UitgeversMaatschappij, v/h Jacques Dusseau \& Co. p 654.

5 State Archives Cape Town, C 512, Incoming Documents 1685-1687: 16 November 1687.

6 State Arhives Cape Town, C 512, Incoming Documents 1685-1687: 19 December 1687

7 Resolutions of the Political Council 1681-1707: 28 November 1689. Suid-Afrikkaanse Argiefstukke, Kaap No 1, Kaapstad 1957.

8 Rijksarchief Den Haag, VC 168: Letter from Pierre Simond to the Lords XVII, 15 June 1689

9 State Archives Cape Town C 418, Incoming Documents, 17 December 1690

10 Sate Archives Cape Town, Outgoing Documents (1691-1692): 29 June 1691

11 State Archives Cape Town, Outgoing Documents (1699-1700): 2 July 1699

12 Colonial Archives 261, The Hague, Resolutien Here XVII(1699-1700): 22 June 1700

13 C Spoelstra, Bouwstoffen voor de Geschiedenis der Nederduitsch-Gereformeerde Kerken in Zuid-Afrika

II, p 602 Hollandsch-Afrikaansche Uitgeversmaatschappij, Amsterdam, 1906.

14 Church Archives Stellenbosch, G31/1, Resolutions, Church Council Drakenstein (1715-1730): 23

February 1723 . 
From the above we can clearly see how the French were seen in the official circles of the Netherlands during the late seventeenth and early eighteenth century. There was acknowledgement of the fact that they were reformed and that they endured a lot of persecution for the sake of their faith, they were seen as people with a lot of courage and guts and as freedom loving. Exactly these characteristics however also made the Dutch wary that they might be too independent and hard headed. A 1689 it was apparently exactly these characteristics that brought them into conflict with Governor Van der Stel and the Political Council. A situation which made any more French refugees as part of an official colonisation scheme persona non grata at the Cape. We also find in the early documentation that the refugees are identified as French Refugees and sometimes as French Refugees of the Reformed faith, or as French Reformed Refugees. Not once are they referred to as French Huguenots or just Huguenots. It is difficult to explain why this was the case because we know that the term Huguenot was used from very early on in their history. It also raises the question about when in the history of South Africa was it started to call the French Refugees, Huguenots?

Another question to be answered in this regard is how did French refugees in South Africa identify themselves, what did they see as their identity? In his letter to the Lords XVII on 15 June 1689 Pierre Simond more than once refers to his compatriots as "the French" or as "refugees". He starts his letter with the words "After we have lived under oppression and barely had the freedom to even complain or sigh in secret, I consider myself lucky that I can now breath in freedom in the shadow of the honourable Company." ${ }^{15}$ On 9 March 1691, 65 members of the Drakenstein congregation in a letter to the Commander Simon van der Stel and the members of the political Council subscribe to a petition in favour of Pierre Simond in the case regarding the differences between him and Jacques de Savoye, a fellow refugee. They bring to the attention of the Council that they have never heard such insults against a minister as that which Savoye uttered against Simond, "not even in France where ministers were so hated by big and small and where they had free reign to insult ministers" 16 In an answer to the demands of Jacques de Savoye accompanying a letter of May 1691 to the Governor and Council, Pierre Simond starts his answer with the following: "Pierre Simond, minister of the Word, driven from France by the persecution, sent to French refugees at the Cape of Good Hope by the providence of God and the lords of the Eastern Company"17 In the same document Simond also quotes a letter written by Mr Baudaen a director of the Chamber of Middelburg. He notifies Simond about complaints that were circulating about him and the way in which he manages the congregation. He then continues "You will know, and that is the truth that these poor people, French refugees, are in a strange land to which they fled far away not to be under the dominance of a church like that of the pope of Rome. They departed for the sake of freedom of conscience and to go and live in peace." 18 In June 1703 a request signed by the Rev Henri Beck, the successor of Pierre Simond, elder Francois du Toit and deacons A de Villiers and A Vivier, is addressed to the Lords XVII. In the request they point out that the Rev Beck was instructed to preach only in Dutch while the majority of the congregation did not understand Dutch and could not follow a sermon in that language. They point out that out of a total of one hundred and sixteen married an elderly persons there are only about 25 that understand enough Dutch to follow a sermon in that language. They request the Lords XVII to allow the minister to preach in French once every two weeks. They express their goodwill towards Dutch and would that their children had more opportunities to be taught in Dutch. They also promise to attend the Dutch services regularly.

15 Rijksarchief Den Haag, VC 168: Letter from Pierre Simond to the Lords XVII, 15 June 1689

16 State Archives Cape Town, VC 169, Letter from Drakenstein Congregation to the Political Council

17 State Archives Cape Town, VC115: Letter from Pierre Simond to the Governor and Council, May 1691.

18 State Archives Cape Town, VC115: Letter from Pierre Simond to the Governor and Council, May 1691. 
Also very important for this article is the way they identify themselves in this letter. They recognise in truth the great favour which has been bestowed upon them during the past 14 to 15 years and they are grateful for that. "In a time when their property was taken from them and they were driven from their fatherland it pleased them (the Lords XVII) in their kindness to settle the French in this land." Under the wise and just government of the honourable and reasonable Mr van der Stel they enjoy in peace and tranquillity the fruits of the land. "But even more is the fact that they enjoy freedom of conscience as well as the free and open exercise of their faith (which is the most precious thing on earth and for the sake of which they left their fatherland and their people) for which they were given a French minister, the Rev Simond." ${ }^{19}$ Apparently the request was granted because we read in the resolutions of the church council of 1715 and on 8 May 1718 that services were held in both Dutch and French. ${ }^{20}$ By 1723 there are only 25 or 26 "old French" left and so the French language disappears at the Cape and outlaying districts.

No further documentation of a specific French refugee identity is known during the eighteenth century. The Drakenstein congregation in effect became a Dutch Reformed Congregation. From reports we know that the congregation during the eighteenth century was seen as a lively and one of most spiritual was at the Cape.

At least up until 1703 we know that the French refugees were quite aware of their identity and that it entailed persecution and refuge for the sake of freedom of conscience and the right to exercise their reformed faith in freedom. They identify themselves as French Refugees for whom freedom of conscience and the free and open exercise of their faith are the most precious things on earth.

\section{FIRST COMMEMORATION EFFORTS 1824 AND 1851}

In 1806 the Cape became a permanent British colony. This had very far reaching consequences in terms of ecclesiastical, educational and social development at the Cape. With regard to the relationship between church and state the British pretty much had the same view as the Dutch the state both protected and controlled the church. For the first time the state granted permission that the Dutch Reformed congregations may assemble in a synod the first of which was held in 1824. The congregations multiplied throughout the Cape colony, educational institutions came about and slowly but surely a "Dutch-French=Afrikaner" nationalism developed in response to the British rule who tried to anglicize both the church and the educational system at the Cape.

1824: In 1824 the first volume of Het Nederduitsch-Zuid Afrikaansch Tijdschrift, the first Dutch language general newspaper in South Africa, was published under the editorship of Abraham Faure (1795-1875) - it would continue until 1843. It was an undertaking in co-operation with Thomas Pringle who was responsible for the English edition of South African Journal - an English paper similar to the Dutch edition. Only two editions of the South African Journal appeared before Lord Charles Somerset stopped its publication for political reasons. Abraham Faure was the great grandson of the French refugee Antoine Alexander Faure who arrived at the Cape in 1714 and then settled in Stellenbosch. Apart from really pioneer work in many areas like publishing, education, church and cultural undertakings Abraham Faure was also the father of the idea of a Dutch Reformed Theological Seminary where students from South Africa could do their theological training in South Africa. The seminary opened it doors in Stellenbosch in 1859 as the first institution for theological training in South Africa. The Seminary facilitated

19 State Archives Cape Town, VC 169: Request Drakenstein Congregation to the Lords XVII, June 1703.

20 Cape Church ArchivesG31/1, Resolutions of the Church Council Drakenstein (1715-1730), 17 February

1715 and 8 May 1718. 
the establishment of schools in Stellenbosch and eventually also the birth of the University of Stellenbosch. He was also one of the founder members of what is today known as the University of Cape Town. ${ }^{21}$ In 1849 Faure became the first editor of the newly established De Gereformeerde Kerkbode (The Reformed Church Messenger). He remained editor until 1868.

In the very first edition of the Nederduitsch Zuid-Afrikaansch Tijdschrift in $1824{ }^{22}$ the French refugees surface again when Faure publishes an article on "Gedenkteeken Ter Eere der Fransche Vlugtelingen" (a Memorial in Honour of the French Refugees). From the article itself it looks as if the content was given to him by descendants of the French Refugees. The article is the very first plea to commemorate the Refugees in South Africa. The article points out that various memorials have up to then been erected in South Africa to commemorate persons who ensured the safety of the colony (volksplanting). "However no memorial has been erected to commemorate earlier events of which our fathers tell us." 23 Faure writes that he was therefore very happy when he received what follows and saw that the descendents of the "French Protestant Refugees, are proud of their descent, and wanted to keep the memory of their brave ancestors alive through the establishment of a memorial in their honour. It was especially necessary in their times (1824 PC), when an indifference and coldness towards religion could be seen, to remind the descendants of those pious people what their ancestors had over for their religion so that the descendants of those people, through the grace of God, could be warned to be careful of all irreligiousness and idolatry and be encouraged to keep on serving God faithfully, the God for whom their ancestors were persecuted and why they sought out these parts of the world."24 Faure then continues by quoting the letter which he received to publish. This is a remarkable document which gives insight into how the descendants of the French refugees saw themselves by $1824-136$ years after their forefathers arrived at the Cape.

"The year 1685 will always be kept as an important memory by the confessor of Reformed faith. In that year, on the cruel command of Louis XIV, the Protestants in his kingdom lost their privileges of freedom of religion that was granted to them by Henry IV and the whole of France executed a bloodbath against those who are of the Reformed Religion. The confessors of the true religion were persecuted in an inhuman way. Those that could, fled to England, Holland, America while some sought refuge in this colony, to exercise their religion undisturbed amongst the then wild and rough inhabitants of Africa. We then, the descendants of those virtuous and pious people who sacrificed blood and goods for the sake of God and the truth; we who were blessed by Providence in these parts so bountiful, that we can still confess the same religion that our ancestors sacrificed all timely pleasures for - we decided to build a memorial in honour of our forefathers; vivify our memory of them; encourage future generations to follow the footsteps of our forefathers on the way of true piety and we wish to do it on the place where we can still see some remains of the first dwelling of the persecuted French Protestant Refugees.

And who is there amongst their descendants who refuses to contribute something? Who is there so bereft of any feeling of own worth, that will not see it as an honour to show the value of their descent? Who's heart does not already jump with joy to be able to show his gratitude. Yes we expect that every descendent of those pious men will not hesitate to give at least one penny for this worthy cause.

NB. We also request that if there are any memorabilia in the families of descendants, to lend

21 H A Heyns, Faure Abraham. In: W J de Kock \& D W Kruger, 1986. Suid-Afrikaanse Biografiese

Woordeboek, Deel II. Raad vir Geesteswetenskaplike Navorsing. Goodwood, Kaapstad, Nasionale

Boekdrukkery, p 233-237

22 Nederduitsch Zuid-Afrikaansch Tijfschrift, Januarie-April 1824.

23 Nederduitsch Afrikaansche Tijdschrift, 1824, first edition, 69.

24 Nederduitsch Afrikaansche Tijdschrift, 1824, first edition, 69. 
that to the Commission (which will be chosen in due time) so that they can compile a record to be kept in the Memorial.

Those who desire to be of help in this worthy cause are requested to make known their names and contribution, and when sufficient subscriptions are received, a Commission from the subscribers will be appointed to gather the subscriptions and complete the project.

Anybody else than the descendants of the French Protestant Refugees are also requested to sign and to place after their name, the people (tribe) from whom they come.

The contributions, which are already many, can be made at Mr J F Beck, in Longstreet $\mathrm{nr}$ 65."25

In the second edition of his book Di Geskidenis van ons Land in di Taal van ons Volk in 1895, (the first edition was in 1877), a first attempt to write the history of South Africa "Ons Land" in Afrikaans was made by the Rev S J du Toit. On p 49 he gives a list of the names of Huguenot descendants that made contributions for the proposed memorial. ${ }^{26}$

In the second edition of the newspaper, May-June 1824 the oath that the French Refugees had to take on their coming to South Africa is published and in the third edition (July-August 1824) we find the Bylaws of the 1688 undertaking in both French and Dutch.

The article in the first edition of the newspaper from 1824 brings forward some remarkable information about the French refugees and their memory and identity in South Africa. After being absent form historical documentation for the larger part of the eighteenth century we find them back in the very first edition of the first Dutch newspaper in the history of South Africa Het Nederduitsch Zuid-Afrikaansch Tijdschrift. They are still identified as French Refugees, and clearly the memory of what they experienced in France, especially in 1685, concurs with what we read in the documents of the late seventeenth and early eighteenth century - it is not and invention of later generations. It is also still recognised that they fled for freedom of religion and that they exercised that right at the southern tip of Africa. We do not know who wrote the article but it is clear that there is a memory of their forefathers amongst the descendants of the French and this memory is now (1824) combined with a desire to build a memorial in their honour and to pass their values on to future generations. Even if one gets the impression that "the forefathers" are perhaps one-sidedly seen as people who, all without exception, are representatives of those very high religious values it is nevertheless significant that "the forefathers" are remembered and that there is a desire to commemorate them. There is also the idea that the whole effort for a memorial must be organised through the appointment of a committee with a list of subscribers - a Society? - all of this is definitely on the agenda. Can one hear sounds of an upcoming nationalism against the British colonialism when the descendents of the French are reminded of the value of their descent and when other members of society (the Dutch?) are requested to also sign on and to indicate from which people (tribe) they descend?

Differences of opinion about the undertaking itself as well as about the secretary and treasurer who were not of pure Refugee ancestry brought about that nothing came from this effort.

1851: On the $15^{\text {th }}$ of May 1851 a meeting was held on the farm of Mr J E de Villiers Louw under the chairmanship of Mr D J Joubert in the Groot Drakenstein valley. The following resolution was taken: "This gathering acknowledges the huge lack in proper education that exists in Groot Drakenstein at the moment amongst the members of the Reformed Church. Amongst the poor members there are quite a few children who are growing up without a proper education in the

25 Nederduitsch Afrikaansche Tijdschrift, 1824, first edition, 69-71.

26 S J du Toit, 1895, Di Geskidenis van ons Land in di Taal van ons Volk. Tweede Uitgaaf. (Aangevuld tot 1895, en vermeerder met Bylage). Paarl, D F du Toit \&Co., Beperkt, Drukkers en Uitgewers. 1895. 
exercise of Letters. The meeting therefore decides that a school institution should be established - (as near as possible to the centre of Groot Drakenstein) under the name of the Groot Drakenstein Institution of Education and Schooling in co-operation with the Paarl Reformed Church" ${ }^{27}$ At the same meeting it was also decided that the children of poor parents would receive free education or at a much reduced price. Pupils that lived far away from the school would also pay less school fees than those children who lived nearer to the school. The teacher had to be a member of the Dutch Reformed Church and a person who leads an exemplary ethical life. The teacher also had to be qualified to teach in Dutch, English, writing, bookkeeping, geography, church and general history and had to be able to catechize the children and if possible also teach them to sing. The teacher would also have to be personally approved by the minister of the Dutch Reformed Church in the Paarl. ${ }^{28}$ At a subsequent meeting on 29 July 1851 it was decided to use the land which Mr du Pree donated, because there were already rocks and clay on the land and more than enough water. The land was also situated along the road that the people from Groot Drakenstein used to go to church and it was near to the centre of Groot Drakenstein. ${ }^{29}$ On 15 August 1851 it was further decided that effort had to be made by Mr C C de Villiers to have the so called "Oude Kerk Grond" (the Old Church Land) added to the donation of Mr du Pree increasing the total of land to about 3.5 morgen. That the inhabitants of Groot Drakenstein were well aware of the meaning of the "Oude Kerk Grond" can already be seen from the unanimous resolution of 29 July 1851: "that while the school is going to be erected on the same place where the first public worship of the French refugees was held, another proper name should be added from the history of the French Protestant Refugees so that the school should at the same time be a memorial-pillar to commemorate them. The building must be built in the form of a commemorative-pillar; because this school must serve both as a memorial in honour of our forefathers the French Protestant Refugees and for the education of our youth as members of the Reformed Church." ${ }^{30}$ On 1 October 1852 the proper name which was mentioned in the resolution of 29 July 1851 was used for the first time when it was moved by Mr H F de Villiers and seconded by Mr D J Joubert "that the school building be given the name "Simondium" in memory of Pierre Simond, the first minister of the French Protestant Refugees who for a few years held their worship services on the place where the building is currently being built." 31 Today that whole area is called Simondium. The meeting of 29 July also appointed the following board of directors: D J Joubert (chairperson), H F de Villiers (secretary), J W Louw (cash-keeper), P F Hugo, J P du Pree, F J Malherbe and J S Marais.

It was decided that the Memorial for the French Protestant Refugees at "De Oude Kerkgrond"(the Old Church land) or Simondium as it is called today would be inaugurated religiously on 6 April 1853, ${ }^{32}$ exactly 201 years after Jan van Riebeeck landed at the Cape of Good Hope and a date which he (Jan van Riebeeck) in 1654 declared had, to be kept "to God's honour and with thanksgiving as a fixed day of thanksgiving and prayer" so that it may

27 Minutes of the founding meeting 15 May 1851. In G B A de Villiers, Niel Marais \& M L Wiese, 1956, Het Sticht Simondium 1852-1956. Gedenkboek opgestel by geleentheid van die inwyding van die nuwe skoolgebou Pierre Simond op 30 November 1956. Pro Ecclesia-Drukkery, Birdstraat, Stellenbosch. p 21.

28 Minutes of the founding meeting 15 May 1851. In: G B A de Villiers, Het Sticht Simondium 1852-1956.

Gedenkboek, p 21.

29 De Villiers, Gedenkboek, p 21.

30 Notule van vergadering van 29 Julie 1851. In: G D B de Villiers 1956, Gedenkboek, p 22

31 Notule van vergadering van 1 Oktober 1852, In: G D B de Villiers 1956, Gedenkboek, p 24

32 De Villiers, G D B, Niel Marais en M L Wiese (reds), 1956, Het Sticht Simondium, 'n Skoolinstelling en Gedenksuil. Gedenkboek opgestel by geleentheid van die inwyding van die nuwe skoolgebou Pierre Simond op 30 November 1956. Pro Ecclesia-Drukkery, Birdstraat Stellenbosch. 
never be forgotten by their descendants." ${ }^{33}$ On the same day the school was also opened. The inauguration ceremony was conducted by the Rev G W A van der Lingen from the Paarl. A call was also put out that anything antique that the "French Protestant Refugees" brought to the Cape, along with ancestral lists of names, histories or any information with regard to them that could help to enliven their history, be entrusted to the board of directors to be kept in the safe room. ${ }^{34}$ It is not sure whether the safe room in the commemoration pillar was ever used for the purpose for which it was built because by 1 July 1854 there is a request by the Reading association to place books for a library in that part of the building. ${ }^{35}$

In the documentation about the school-memorial we find that the descendants of the French still call their ancestors and themselves French Protestant Refugees - still no mention of "Huguenots" in South Africa. The whole effort of 1851 is very strongly linked to the Dutch Reformed Church and the religious character of the event. The question can be asked whether it was purely chance that the date of 6 April 1653 was chosen for the inauguration of the school or was it a deliberate choice to also adhere to the command of Jan van Riebeeck from 1654. The main aim of the school-memorial was to provide proper education in Dutch for the people from Groot Drakenstein. The condition of education for the Dutch speaking part of the population at the Cape was really dismal at that time. Everywhere there were efforts by Dutch speaking leaders to put this right. That a school-memorial for the French Refugees was also used for this purpose show how completely integrated the French by then were with the Dutch. Their church was also completely integrated with the Dutch Reformed Church and they made common cause with the Dutch for the education of their children while at the same time commemorating their ancestors. It is also clear that there was some form of organisation amongst the descendants of the Refugees. There were committees and deliberate efforts by a community to undertake the building of a memorial as well as to collect ancestral memorabilia which all shows the embryo of an organisation. This can lead us to the conclusion that all of this was a forerunner of the eventual establishment of a Huguenot Society of South Africa. In the decades to come there would be more attempts.

\section{TWO SCHOOLS 1873 AND 1882}

1873: During the first half of 1873 Andrew Murray drew up a memorandum ${ }^{36}$ that would serve before the a meeting held in the Dutch Reformed Church of Wellington on 25 June. The memorandum contained a proposal that a Huguenot Seminary be established in Wellington. The main aim of the Seminary was to be a institution where a thorough Christian education for the sake of the country would be given to young girls to enable them to become teachers all over South Africa and also to equip young women to be ready to work in any place to where God may call them in his Providence. ${ }^{37}$

Murray also says in the memorandum that at a Mission Conference in 1872 the desirability of a memorial was discussed to commemorate the coming of the Refugees, they who left their homes and families to serve God in freedom and truth. And what better way to answer to the calling than to erect a school dedicated to commemorate them in these parts which are so

33 Jan van Riebeeck, Daily Journal Part I, 1651-1655, 6 April 1654. Publication of the Van Riebeeck

Society. Cape Town, Balkema 1952.

34 G D B de Villiers, Gedenkboek, p 26.

35 G D B de Villiers, Gedenkboek, p 26.

36 Andrew Murray, 1873, Memorandum De Hugenotenschool te Wellington. In: Du Plessis, J,1920, Het

leven van Andrew Murray. Uitgave van de Zuid-Afrikaansche Bijbel Vereniging. Kaapstad. p 285.

37 Du Plessis, J,1920, Het leven van Andrew Murray. Uitgave van de Zuid-Afrikaansche Bijbel Vereniging. Kaapstad. p 293. 
holy to us, parts where the dispelled "Huguenots" first found rest and could again serve God on their own land. It is in the trust that the Huguenot school in Wellington will answer to this holy intention that Murray had decided to get ready and to build the Huguenot Seminary. ${ }^{38} \mathrm{De}$ Gereformeerde Kerkbode of 25 November 1873 reports about the inauguration of the buildings of the Seminary on 25 October 1873. A large number of the members of the synod of the Dutch Reformed Church, which was in session during those days in Cape Town, came to Wellington by train. The Moderator of the Synod opened the gathering while an address was given by prof $\mathrm{N} J$ Hofmeyr of the Theological Seminary in Stellenbosch. The Kerkbode also reports that an old "Huguenot" relic, namely a piece out of one of the walls of the first building that served as school and church for the first "French Refugees" was shown by the Rev George Morgan during his speech at the meeting.

With this development we find that for the first time in South Africa, as far as could be established, the term "Huguenot" is used as indication of the "French Refugees". The terms "Huguenot" and "French Refugees" are used by the Kerkbode in its report of the occasion while Murray writes about "refugees" and "Huguenots" in his memorandum. It is not clear when the term "Huguenot" came into use in the South African context. A Good guess can be that it must have been somewhere between 1867 and 1873. In 1867 the book of Samuel Smiles The Huguenots: their settlements, churches, industries in England and Ireland was published in London by J Murray. From information years later we know that the book was known at the Cape as a British colony and the question is whether it was perhaps instrumental for the use of the term "Huguenot" in South Africa? The main aim of the Huguenot Seminary in Wellington was the education of young girls to become teachers and to prepare them for Christian service in any area to which God sent them. One can say that the Huguenot Seminary was about education and mission. According to many reports it was a great success. The name of the Seminary was the Huguenot Seminary because it was built in a town and area which was known as an area where many Huguenots settled. It was the intention that it must serve as a memorial for the Huguenots but as far as can be gathered it was never the intention for the Seminary to be a place where Huguenots memorabilia or lists of Huguenot descendants would be kept or where any form of a Huguenot Society would be housed. The main language used at the Seminary was English just as most of the staff were English. This would lead to the establishment of another Huguenot Memorial School in Daljosaphat by the Rev S J du Toit in February 1882.

1882: By 1876 the Rev S J du Toit of the Paarl felt that nothing has yet been done to commemorate the coming of the French refugees to South Africa in a proper way. By that time the Society for Real Afrikaners (Genootskap vir Regte Afrikaners) with Du Toit as a leading figure, was an upcoming movement fighting for "our language, our people (nation) and our land". Du Toit very well knew that the commemoration of the Huguenots-ancestors would contribute largely to make the Afrikaners (Dutch and French descendants) aware of their national identity amid the denationalising and anglicising influence of the British. At that stage is was the policy of the English government that all the public schools had to be English an no religious education was allowed in schools. The efforts by Du Toit to fight this, would lead to the establishment and opening of the "Gedenkschool der Hugenoten"(The Huguenot Memorial School) on 1 February 1882.

To start with Du Toit wanted to make the Afrikaners well aware of the meaning of the Huguenots. To achieve this he made use of the two journals Die Afrikaanse Almanak a publication of the Genootskap of Regte Afrikaners since 1877, and Die Afrikaanse Patriot. From the first issue of Die Afrikaanse Almanak in 1877 he published articles on the Huguenots and

38 Murray, Memorandum, p 286 
their experiences. Under the pseudonym "Ware Afrikaner" (True Afrikaner) he called on the descendants of the Huguenots to commemorate the coming of the Huguenots to South Africa in a proper way. He had in mind a "big memorial" on which the Huguenot family names and the date of their arrival could be engraved. All Huguenot descendants had to contribute to this effort so that it could be ready by 1888 for the bicentenary commemoration of the coming of the first Huguenots to South Africa. Du Toit was also of opinion that the memorial had to be erected in a place where many of the early Huguenots settled - which could be any one of the Paarl, Wamakersvallei (Val du Charon) - the current Wellington, - Franschhoek or Groot Drakenstein. He also encouraged readers to write their opinions to the office of Die Afrikaanse Patriot. Between May and September 1877 Du Toit published a series of 11 articles on the Huguenots in Die Afrikaanse Patriot. Nothing came from this call in 1877, so Du Toit repeated his call 1880 and also suggested some ideas on how plans could be implemented to get money for the project from all over South Africa. ${ }^{39}$

In 1881 Du Toit again wrote under the pseudonym "Ware Afrikaner" in Die Afrikaanse Almanak. He now had new ideas for the Memorial - a memorial of clay and bricks merely as a honour and an adornment would not be worthy of the memory of the pious Huguenots. A school in the service of the land and the people would be the best and the most useful. He added that every Huguenot knew that "our country and our people needed such a school and the name of the school must be "The Real Huguenot School". The school would have to comply with certain requirements - it had to be:

- a real national school where respect for "our" ancestors; love for "our" people; knowledge of "our" history and a true national feeling would be cultivated;

- a real Afrikaans school where Dutch and English and everything that belongs to a civilised education will be taught thoroughly;

- a real Huguenot school where the spirit of the Huguenot ancestors will be kept and honoured;

- a real Christian school in which the Bible will have a place of honour and be the foundation of all education;

- a real Reformed school where the pupils will be taught the pure dogma and learn to sing the Psalms;

- a real normal training school where teachers will be trained;

- a real educational school for young Afrikaners who wanted to become ministers or doctors etc.;

- a real public school where Boer-children could receive a decent civil education and learn of the most necessary things;

- a real boarding school to which children from all parts of the country could come and be under good supervision;

- a real free school without government subsidies and government supervision;

- a real inexpensive school where poor children would receive education;

- a real Memorial school in which old Huguenot memorabilia, genealogies, portraits etc. could be gathered and kept.

In this proposal Du Toit also saw the fulfilment of his own ideas about Christian-, mother tongueand national education. The school would be the true memorial for the Huguenots in service of their descendants.

On 13 December 1880 Du Toit called a meeting of interested friends to present to them his plans for a Memorial School. Four days later a committee discussed Du Toit's proposal. Other

39 Henn, MMT, 1984, De Gedenkschool der Hugenoten in Kultuur-Historiese Perspektief. In: Huguenot Society of South Africa, Bulletin 22, 1984-1985. p 21-22. 
proposals were also brought before the committee: a memorial plague at the Paarl market square, a fountain for the citizens of and visitors to the Paarl, and even a hydro cure. In the end Du Toit's proposal for a memorial school was accepted. After much planning and hard work the school was opened on 1 February 1882 on the farm Kleinbosch in the Daljosaphat district of the Paarl. Kleinbosch was the farm that belonged to Francois du Toit, who came to the Cape in 1686. Initially the school was housed in the homestead while the cellar was being converted into a school. On 14 March 1883 the new school building was inaugurated - a beautiful Georgian style double storey building with the words "Gedenkschool der Hugenoten 1883" displayed on the roof. So many people attended the function that not everybody could be seated inside the school. D F du Toit and Andrew Murray gave speeches at the occasion. Throughout the whole exercise the people of South Africa were kept informed of developments through Die Afrikaanse Almanak and Die Afrikaanse Patriot. There was indeed very wide support for the school from all over the country as can be seen form letters of support from places like Hopetown and Petrusville in the Northern Cape, Dundee in Natal, Harrismith in the Orange Free State, Richmond in the Karoo, and nearer in the Boland itself places like Rheebokskloof and Wemmershoek.

Initially it went very well with the school but in time there was a shortage of funds and of pupils. There was also resistance to the fact that the school was seen as anti-English and in opposition to English schools like the Huguenot Seminary in nearby Wellington. The theological views of Du Toit was also not much loved and accepted in Dutch Reformed Church circles. All of these factors lead to the undetermined closure of the school by the end of 1888 - the year in which it was supposed to serve as a living commemoration for the bicentenary festivities commemorating the coming of the Huguenots to South Africa. In 1888 both the Rev S J du Toit and his brother were in the Paarl due to the illness of their mother. Both brothers saw it as an ideal opportunity to organise a Huguenot commemoration for 1888. On 18 April 1888 a meeting was held in the Memorial School under the chairmanship of SJ du Toit. Some 24 people from surrounding areas were present. Some see this gathering as the embryo of a Huguenot society in South Africa. The aim of the meeting was to plan a Huguenot commemoration in September 1888. Elaborative plans were set out for this commemoration: The commemoration would take place in the Paarl district because it was especially in that area that the first Huguenots settled in 1688; a music festival would be held in the Paarl under the leadership of S J de Villiers and Mr Rocco de Villiers; a Memorial script signed by the descendants of the Huguenots would be placed in the Simondium Memorial-School to be kept there; a dinner would be held in the Memorial School on Kleinbosch and a cairn would be packed under the old oak tree that was planted by the first owner of Kleinbosch, Francois du Toit. Lastly a committee would be appointed to execute the plan. A next meeting later in 1888 was envisaged but it had to be postponed to 1889 . Eventually nothing happened. All that remained was the Gedenkschool der Hugenoten and that was closed down indefinitely at end of 1888. It reopened on 1 October 1889. Financial difficulties forced it to ask for government aid in 1895. Although it was then subjected to government inspection it succeeded to keep its Christian-national character. After many problems surrounding SJ du Toit and his views and after many tribulations and necessitated changes, the school had to finally close down by the end of 1910.40

The Gedenkschool der Hugenoten is a remarkable chapter in the history of Huguenot commemoration in South Africa. It seems that by 1880 the term Huguenot had become fully accepted in South Africa and although the name French Refugees was still used it is Huguenot that dominates. Again, like in the case of the Huguenot Seminary in Wellington, the commemoration of Huguenots is used to serve another cause than the mere commemoration

40 Henn, MMT, 1984, De Gedenkschool der Hugenoten in Kultuur-Historiese Perspektief. In: Huguenot Society of South Africa, Bulletin 22, 1984-1985. p 21-27. 
of the Huguenots. In the case of Wellington it was education and mission now it is education and Afrikaner nationalism. Nevertheless the commemoration aspect remains very important. The history of the Gedenkschool does not say much explicitly about the values of those early Huguenots, values like freedom of conscience and freedom of religion. Clearly those values are there and they are to be preserved but the cause is now something else. Du Toit and his fellow Patriots are fighting the cause of the Afrikaners and Afrikaans as language. That is why they are not so friendly towards the Huguenot Seminary in nearby Wellington because that English institution threatens to absorb Afrikaans daughters into the English culture and way of doing. $\mathrm{Du}$ Toit and his fellow "Patriotmen" realised that one of the greatest threats to the upcoming Afrikaners was the English oriented public and private schools. That is why the commemoration of the Huguenots through a Memorial School with very specific requirements was such a useful vehicle. It is not to say that Du Toit and his "Medepatriotte" (Compatriots) or even Andrew Murray and his fellow workers were not honest in their commemoration of the Huguenots, but the commemoration was also used with other motives in mind. It is also not to say that the "other motives" were not justified at that time. The British Empire was at its peak, education facilities in the Cape Colony was especially poor among the Dutch population. Also, the Empire increasingly became a threat to the continued existence of the both the Dutch and the French at the Cape, they, who through history, had developed into a new people, the Afrikaners with an own distinct language Afrikaans and who mostly belonged to the same church - the Dutch Reformed Church. In the end the Gedenkschool der Hugenoten did not survive the aims of its builders. But the building itself remains up to this day a commemoration of the Huguenots of South Africa. On 14 March 1998, exactly 115 years after the inauguration of the original Gedenkschool the Afrikaans newspaper Die Burger reported that the school from 1883 was in a dilapidated state, but enough money had already been collected to restore the Gedenkschool der Hugenoten to its original state as a commemoration of the Huguenots and also as a beacon of light in the history of South Africa. ${ }^{41}$ Today the school is governed by a board of Hugenote Gedenkschool Trustees, it is still seen as a Huguenot Commemoration and is used for all kinds of cultural events such as a writing school for Afrikaans speaking pupils from all population groups.

\section{PREPARATIONS FOR THE BICENTENERY COMMEMORATIONS}

31 July 1885: On 31 July 1885 a meeting was held in Cape Town under the chairmanship of the Chief Justice Sir Henry de Villiers. The aim was to plan for a Huguenot festival in 1888. Several proposals were made like the unveiling of a Huguenot memorial pillar in that year. The Chief Justice himself was in favour of the idea that a building be erected for the South African Athenaeum as a memorial to the Huguenots. He also felt that whatever the memorial may be it must be something that will attract attention, not create an image of smallness, exhibit true art qualities and be so designed that through its allegorical image in marble or whatever material, it will truly recall to mind the great event. ${ }^{42}$ A Preliminary committee was appointed comprising of the Chief Justice, church ministers and members form the Legislative Assembly - The Committee members were Sir JH de Villiers, the Revs Du Plessis, Steijtler and Leibbrandt, the honourable JA Combrinck MLC; M L Neethling MLC, JS Marais MLC; DC de Waal MLC; D F du Toit, the Rev prof Marais and Christoffel $\mathrm{C}$ de Villiers who was asked to act as secretary of the undertaking.

From a report in the Cape Times of 3 August 1885 one can gather that the committee was

41 Hugenote Gedenkskool presies 115 jaar oud. Die Burger Woonburger, 14 Maart 1998.

42 Henn, MMT, 1984, De Gedenkschool der Hugenoten in Kultuur-Historiese Perspektief. In: Huguenot Society of South Africa, Bulletin 22, 1984-1985. p 24. 
larger than just the people mentioned in the Zuid-Afrikaan of 1 August. ${ }^{43}$ Without taking a final decision the meeting of 31 July 1885 expressed the opinion that a memorial for the Huguenots must be erected and the balance of money collected for this purpose had to be used to form a fund for the education of poor children, descendants of the Huguenots. ${ }^{44}$ This Meeting was reported in several journals. The Cape Times of Monday 3 August 1885 refers to an article in the Volksblad of 31 July about the same meeting and then gives the following very interesting comments which says quite a lot about how the Huguenots were seen in South Africa at that time:

"From the remarks of the Volksblad and from the omission on the part of the twenty five representative gentlemen to communicate their project to other journals it may be presumed that the descendants of the Huguenots immigrants intend to keep the celebration in their own hands. Otherwise we believe that other colonists, who cherish the memory of a noble struggle for religious freedom would heartily join in the movement. The Huguenot families, having parted with their mother tongue were not the exclusive in carrying out the first social law. The language was sacrificed for the dominant will of the Dutch Government and Mr Theal writes "the intermarriage which after a few years became common between the colonists of different nationalities tended to obliterate all distinctions between them. Mr Theal writes of them: "These were undoubtedly the best settlers the Colony had yet received. The immigrants from the Netherlands were all of one class, but these were of various stations in society. Some had been of high rank in France, others were manufacturers, others again vine-dressers or gardeners. It is from the date of their arrival that the manufacture of wine on a large scale was carried on. The Huguenot blood, therefore was to a great extent the blood of honest peasants and artisans, but blue or red it soon diffused itself in the general stream, and, as Mr Theal remarks "at present there can be very few, if any, Dutch South Africans without a mixture of Huguenot blood in their veins. With respectable pride the Volksblad says - "It is not too much to expect that the descendants of the noblest blood of France should willingly sacrifice a few sovereigns to keep green the memory of their fathers who by their sacrifice have earned immortal fame. We would only extend this pride of race, this inheritance of the best blood of France, to the descendant of the simplest peasant who risked his worldly goods, his liberty and his life, in what he believed to be the highest truth." 45

Although in the end nothing came of the meeting under the chairmanship of Sir Henry de Villiers it reveals very significant information. For the first time there is the idea of a memorial which had to convey an allegorical image that will truly recall the greatness of the coming of the Huguenots to South Africa. From the report on this meeting in the English speaking press in Cape Town we hear of suspicion that a certain group of the colonist population was deliberately not informed of the plans because the descendants of the Huguenots apparently wanted to claim it as something for themselves while the journalist felt that they actually belonged to every colonist in South Africa who could identify with freedom of religion. What is also very interesting is to hear the terms in which the Huguenots of 1688 are described: the best settlers the colony has yet received; the Dutch immigrants were of one class but the Huguenots were from various stations in society - high ranking people in France, manufactures, vine dressers and gardeners, people with the blood of honest peasants and artisans. From the date of their arrival the wine industry bloomed. The article also speaks of "this pride of race, this inheritance of the best blood of France" which should be shared and not kept for only a few descendants. This was a new way of seeing the Huguenots of South Africa - a way which influenced the views about the Huguenots

43 See also De Kerkbode, 7 Augustus 1885, p 359.

44 De Zuid-Afrikaan, 1 August 1885.

45 Cape Times, Monday 3 August 1885.

314 Deel 52, NOMMERS 3 \& 4, SEPTEMBER \& DESEMBER 2011 
for generations to come in South Africa - all of them, without exception, noble people, with noble blood and a noble heritage.

24 August 1885: a public meeting in the Paarl. Already at the meeting in Cape Town under the chairmanship of Sir de Villiers notice was taken of a movement in the Paarl which was of opinion that a country wide committee with representation from various areas had to be appointed so that the whole country could participate in the 1888 festival. The Cape Committee did not support this idea because they saw it as their prerogative to organise both a festival and a memorial. The meeting in the Paarl on the other hand felt that the Huguenot memorial had to be erected in the Paarl because it was there, rather than in Cape Town, that the Huguenots settled originally. The Paarlites were also of opinion that in Cape Town a Huguenot memorial would disappear between all the other monuments in the city. After meeting a deputation from the Paarl it was found by the Cape Town Committee that the ideas from the Paarl were totally unacceptable. So the Cape Town Committee decided that as soon as more than $f 5000.00$ for a memorial had been collected a meeting would be held with subscribers in the Paarl to decide what had to be done with the balance of the subscriptions. A Possible solution for the problem was that Cape Town and the Paarl each organise their own festival and support each other. The Cape Committee rejected this idea and remained adamant that the Huguenot memorial must come in Cape Town and that they must organise it. In the Paarl it was decided that the Huguenots be commemorated by a Wine and Agricultural School. In the end nothing came of either efforts. ${ }^{46}$

\section{THE DUTCH REFORMED CHURCH AND HUGUENOT COMMEMORATIONS}

From June to November 1885 a series of articles appeared in De Kerkbode to bring the commemoration of the Revocation of the Edict of Nantes in October 1685 to the attention of members of the Dutch Reformed Church as well as to descendants of the Huguenots, hoping that as the Reformed Church in France, the descendants of the Huguenots in SA will also partake in the commemoration. Especially the descendants of the Huguenots must be grateful for the "religious freedom" (geestelijke vrijheden) that became their part through the departure of their ancestors from France, and they should show themselves worthy of it. ${ }^{47}$

In the issue of 7 August 1885 it is suggested that on Sunday 18 October the Revocation be commemorated religiously in all the congregations of the Dutch Reformed Churches. It is also already known what the programmes will be in certain congregations like Wellington and Franschhoek. In Franschhoek the youth movement will present a programme while in Wellington the cornerstone of the new hall of the Huguenot school will be laid and a booklet containing the history of the Huguenots will be published. The editor also suggests that it might be a good thing if Reformation Day for that year also be commemorated on 18 October. It is also the prayer of the editor that the spirit of the Huguenots being one of faith and sacrifice to serve the Son of God will revive in all their descendants. ${ }^{48}$ In the same edition there is also notice of the meeting that Sir Henry de Villiers called in Cape Town the previous week and that a public meeting to discuss the festivities in 1888 will be held on 7 August. ${ }^{49}$

46 De Kerkbode, no 35, Vrydag 4 September 1885; p 400; Henn, MMT, 1984, De Gedenkschool der

Hugenoten in Kultuur-Historiese Perspektief. In: Huguenot Society of South Africa, Bulletin 22, 1984-

1985. p 24.

47 De Kerkbode, 5 June 1885, p 261.

48 De Kerkbode, 7 August 1885, p 359.

49 De Kerkbode, 7 Augustus 1885, 359. 
In De Kerkbode of 28 August there is the follow up of a three column article about the Edict of Nantes. ${ }^{50}$ This is followed by another article on the Edict of Nantes on 4 September together with a report by $\mathrm{J} \mathrm{H}$ du Plessis on developments between Cape Town and the Paarl. ${ }^{51}$ The edition of 11 September contains another sequence on the Edict of Nantes. ${ }^{52}$

On 25 September 1885 the sequence on the Edict of Nantes is continued in a five column article and on $\mathrm{p} 432$ four books on the Huguenots are mentioned in response to requests for suitable reading material. The first is the Dutch translation from French in 1854 by Dr Changuion of the work Geschiedenis der Fransche Protestantsche Vluchtelingen van de Herroeping van het Edict van Nantes tot op onzen tijd. Changuion was a teacher in Cape Town. It is very interesting to note that in 1854 Changuion still uses the term Fransche Protestantsche Vlugtelingen (French Protestant Refugee).

The second book is from Smiles The Huguenots in England ( we know this book was first published in 1867 though the article does not mention the date of publication). The third work is also by Smiles The Huguenots in France. Both these books are called very readable books by the editor. The son of the then editor JH du Plessis, Prof J du Plessis later wrote a standard biography on Andrew Murray who was the founder of the Huguenot Seminary in Wellington in 1873. This strengthens the opinion that it was through the work of Smiles that the term Huguenot became to be used in South Africa after 1867. The fourth book is from the Religious Tract Society Memorial of a Huguenot Family. 53

On 2 October the Editor of De Kerkbode recommends a small book De Herroeping van Het Edict van Nantes (22 October 1885) to his readers and encourages them to buy it, read it and distribute it. ${ }^{54}$

In the edition of 9 October 1885 it is reported that the Reformed Church in France is planning to build a new church on the place where the Charenton Church stood in 1685 before it was demolished. The question is asked whether the descendants of Huguenots in SA won't participate in the project by taking a collection on the $18^{\text {th }}$ that can be sent to France? In a letter from French missionaries in Basutoland it is stated that the French Protestants will very grateful if they hear that the Huguenots in South Africa want to unite with them in the commemoration to maintain the unity of origin and faith that could not be broken during two centuries. The editor himself then poses the possibility that the Huguenots in SA can help the Reformed Seminaries in Paris and Montauban financially since they are struggling due to the withdrawal of subsidies by the government. It would not so much be the amount of money but the display of sympathy that will count. He then again asks for a collection on the $18^{\text {th }}$ or $25^{\text {th }}$ of October and suggests that it be left to the church leaders to decide which one of the two institutions must be helped. It can also be left to the French Reformed Church itself to decide..$^{55}$ In the same edition there is also a short article with statistical information about the Reformed Church in France since the restoration of 1878.56

De Kerkbode of 23 October 1885 contains a report on the different commemorations of the Huguenots that were held all over the country and who the people were that made speeches. Cape Town, Wellington, Franschhoek, Paarl, Cradock and Pearston are mentioned . In Wellington Sir Henry de Villiers was the keynote speaker. At the end of that commemoration a letter from the Huguenots in South Africa addressed to the Huguenots in France would be signed by two

50 De Kerkbode, 28 Augustus 1885, 378-388.

51 De Kerkbode, 4 September 1885,399-400

52 De Kerkbode, 11 September 1885

53 De Kerkbode, 25 September 1885, 432

54 De Kerkbode, 2 October 1885, 440.

55 De Kerkbode, 9 October 1885, 450-451

56 De Kerkbode, 9 October 1885, 451 
or three representatives of Huguenot families present at the meeting. It is also envisaged that a booklet and four accompanying lithographs with the symbols of the French, Dutch, Scottish and South African churches, listing the main events of the Reformation will be published. ${ }^{57}$ At the end of article there is prayer by the author of the article "May God grant that these memorial festivities have an ongoing blessing for our whole church." 58 At the memorial festival in Pearston Mr J J Janse van Rensburg M.L.A. was the last speaker. He earnestly called upon all those present that a memorial for the Huguenots be erected to remind us of the coming of the Huguenots to South Africa. Nearly all the members of the Dutch Reformed Church have Huguenot blood in their veins. He also proposes the names of members from the congregation to raise funds and build a memorial. 59

De Kerkbode of 6 November again contains reports of the commemorations in the places already named but then also adds the name of De Wetsdorp in the Orange Free State where the Presbytery of de Wetsdorp assembled for the first time ever with members from places like Edenville and Philippolis. Part of the meeting was a conference with the theme De Herroeping van het Edict van Nantes (The Revocation of the Edict of Nantes). It is reported that the attendance at all the services were exceptionally high. ${ }^{60}$

It seems as if, with all the articles in De Kerkbode of 1885, that the Dutch Reformed Church took the lead in the commemorations of the Revocation of the Edict of Nantes, while different towns and cities quarrelled with each other about the what and where of a Huguenot memorial. With that it also seems as if the Huguenots of South Africa became something that the Church claimed. The prayer of the journalist in De Kerkbode is that the memorial festivities will be an "ongoing blessing for our whole church". The memorial festivities were held in cities and towns very far and wide apart in South Africa and many people were involved. The mentioning of the books of Smiles confirms not only that they were known in South Africa but that they apparently also had a substantial influence on the thinking about the Huguenots.

The Dutch Reformed Church would also in the next decades play a significant role in the commemoration of the Huguenots.

In January 1886 the Dutch Reformed Church started to plan a festive programme to commemorate the coming of the Huguenots to South Africa in 1888. The Synod of 1886 decided that a building must be erected in Cape Town as a hall for the meetings of the Synod with committee rooms and a room for a church office. It was also decided that everything possible must be done that the cornerstone of this Huguenot Memorial can be laid in April 1888. The Revs Andrew Murray and JH Hofmeyr were asked to publish a letter informing church councils and members of the Dutch Reformed Church that the Hall and a Synodical church office was to be built as a Huguenot Monument. This undertaking could not be completed for 1888 , resulting also in the proposed festivities not taking place. Eventually the Huguenot Memorial Hall in Queen Victoria street in Cape Town was completed in 1903. By 1919 the building became to small and synod decided to sell the building. New instructions were given and by 1924 a new building with the same name neared completion. At that point in time this was about the only lasting Huguenot Memorial in South Africa, apart from the school in Simondium. For 37 years that hall would serve as a meeting place for the Synod of the Dutch Reformed Church in South Africa (i.e. the Cape Province). The synods of the other provinces met at other locations. In 1962 the General Synod of the Dutch Reformed Church constituted in the Huguenot Memorial Hall, re-uniting all the provincial synods of the Church in a General Synod. On 21 October 1965 
the Church moved from the existing Huguenot Memorial Hall to a location at the upper end of Queen Victoria Road. Unfortunately the name was also left behind and today the office block that was erected on the place of the original hall carries the name of Huguenot Chambers offices for the advocates of the Cape High Court. In 1988 the year of the tercentenary festivities, Synod decided to once again name the meeting place of Synod The Huguenot Memorial Hall. When this building was sold by the Church in 1998 the name Huguenot Memorial Hall was unfortunately also lost and one can say that to a large extent the co-guardianship role of the Dutch Reformed Church over the Huguenot Heritage in South Africa also came to an end. ${ }^{61}$

\section{QUARTER MILLENNIUM COMMEMORATIONS 1939 -1967}

After he had been asked from various sides Senator F S Malan convened a meeting in Cape Town on 11 December 1936 to discuss the desirability of a Huguenot festival and the building of a monument in 1938 - 250 years after their arrival at the Cape. Interested people from Cape Town and nearby towns attended the meeting. Thoughts were exchanged about the importance of the Huguenots and everybody agreed that something substantial had to be done to keep the memory of the Huguenot ancestors alive. Since 1938 had already been announced as a Voortrekker centenary year to commemorate the trek of the Voortrekkers into the northern and eastern parts of South Africa, it was decided that it would not be a good idea to have the two festivals in the same year and that the Huguenot festival would be moved to 1939. The meeting appointed a central committee with members from Cape Town, Stellenbosch, Franschhoek and the Paarl. The committee under Chairmanship of Senator F S Malan would be known as the "Huguenot-Quarter Millennium-Memorial Festival Committee" (Hugenote KwartmillenniumGedenkfeeskomitee). The main aim of the festival was to be: the celebration of the Quarter Millennium Memorial feast; the building of a Huguenot Monument and the compilation of a Huguenot family register. From 15-18 September 1939 memorial celebrations were organised in Stellenbosch, Franschhoek and the Paarl with symbolic tableau's and historical scenes to show the role that the Huguenots played in the growth of the Afrikaner people ("Afrikanervolk") in the fields of religion, culture, agriculture and other areas. Memorial services were held in Simondium and the Paarl. In the Paarl the old parsonage was restored and inaugurated as a Huguenot Museum where antiques out of the Huguenot history would be kept. A film was made of all the festivities to be kept in the archives for the sake of next generations. Due to the second world war which broke out in those days the northern provinces of South Africa decided to postpone their festivities indefinitely. In the end the 1939 festivities were restricted to the areas where the Huguenots settled by $1688 .^{62}$

As part of the 1939 festivities there were also three other events. On 18 September 1939 Senator F S Malan spoke at the inauguration of the Springfountain in Wellington referring to the fountain as symbol of the Living Water - the Word of God - and that it was that Word that sustained the Huguenots through the times of religious persecution. It was also that Word that inspired them to have such an enormous influence for the best on their descendants in South Africa, to become a nation ("Volkswording").

On 6 May 1942 three panels were unveiled against an outside wall of the library in Stellenbosch depicting the history of the Huguenots in three life size panels - the departure from France, the voyage to South Africa and the settling at the Cape under the three themes of religion, love of freedom and labour.

61 Coertzen, P, 1988, The Huguenots of South Africa 1688-1988. Tafelberg, Cape Town. p 148.

62 Die Hugenote-Monument op Franschhoek. Gedenkskrif uitgegee deur die Hugenote-Gedenkfeeskomitee en opgetstel deur Prof Dr E C Pienaar, voorsitter, ter geleentheid van die plegtige inwyding van die Hugenote-mnument te Franschhoek, op Saterdag 17 April 1948. p 3-4. 
The third project that came from 1939 was to gather information on the Huguenots so that a register could be compiled. About 75000 forms were sent out to people with Huguenot names in the Union of South Africa, South West Africa (Namibia), Rhodesia (Zimbabwe), Tanganjika, Kenya as well as other places overseas. Initially there was a good response but due to the war interest soon dwindled. Eventually only about 12000 forms were returned. Families that responded most were Du Plessis (700), Du Toit (600), De Villiers (500), Nel (500), Joubert (450), Marais (450), Naudé (400). The results were processed and checked against other documents with a view to establish more or less a genealogy of each family. By 19426000 names of the families Jordaan, Joubert, Lombard, Malan, Malherbe and Marais had already been processed. Towards the end of 1942 this whole project under the guidance of Mr S F du Toit had to be stopped temporarily due to the dismal circumstances brought about by the war and the increasing work regarding a Huguenot Monument. The money that was allotted for the project had to be rerouted for the increasing costs of the Monument.

By 1946 the whole project was transferred to prof B Lombaard of the University of Pretoria. The idea was that the project would be completed by about $1960 .{ }^{63}$ Round about 1960 the questionnaires were sent to the newly established Huguenot Memorial Museum where staff members started working on the questionnaires, comparing the information with that in other documents. Today, as work in progress, family registers and genealogies on most of the Huguenot families that came to South Africa have been compiled and are kept at the Huguenot Memorial Museum ${ }^{64}$. Many other Huguenot descendants have also done research on their families and also had their research published. The Huguenot Society of South Africa has also recently started a programme to publish Huguenot genealogies, and there continues to be a lively interest in the subject among both white and brown South Africans. Apart from the genealogies by white Huguenot descendants it is found that many a brown family with Huguenot surnames and ancestry are also interested in genealogical research. Among these families there are Mr Pieter de Villiers (current coach of the Springbok rugby team), Mr Elias P Nel, a South African poet; the Marais family of whom Mr. Peter Marais was a former Premier of the Western Cape Government, and then also the Mouton, Theron, Rossouw and De Klerk families. ${ }^{65}$

From about 1885 to 1939, the Dutch Reformed Church was one of the chief guardians of the Huguenot heritage of South Africa. During those years, in fact, only the Church maintained a Huguenot memorial, its synodical buildings. Missionary training was one of the concerns of the Huguenot Seminary in Wellington.

The Commemoration festivities of 1939 was a success and it involved many South Africans. It is unfortunate that festivities in the Northern Provinces of SA did not go through due to the war. Although ideas of religious persecution and freedom of religion did play a clear role one also hears just as clearly the undertones of the rising Afrikaner nationalism when the Huguenots are honoured for the role they played in the becoming of the Afrikaner people (Afrikanervolk). Rising Afrikaner nationalism was a fact of the day and must be seen against the background of all the setbacks that the Afrikaners experienced during the Anglo-Boer War (1899-1922), the first World War and again with World War II. For the first time Afrikaners felt that they were coming to their own in their own country. One can criticize the fact that the French Refugees, the Huguenots and their history were used for this purpose. At the same time it cannot be denied that the Huguenots together with the Dutch eventually formed the Afrikaner people and that

63 Die Hugenote-Monument op Franschhoek. Gedenkskrif uitgegee deur die Hugenote-Gedenkfeeskomitee en opgetstel deur Prof Dr E C Pienaar, voorsitter, ter geleentheid van die plegtige inwyding van die Hugenote-monument te Franschhoek, op Saterdag 17 April 1948. p 13-16.

64 Information supplied by Mrs Juna Malherbe, Huguenot Memorial Museum, Franschhoek, August 2011. 65 Information supplied by Ms Juna Malherbe, Huguenot Memorial Museum, Franschhoek, August 2011. 
they struggled together for the Afrikaans language, Afrikaner culture and Afrikaner nationalism for many decades. However the role and influence of other groups like the German immigrants in the building of the Afrikaner people must also be remembered with gratitude. What is also conspicuous in the 1939 commemorations is the absence of the Dutch Reformed Church in the documentation about the festivities. This is of course not to say the Dutch Reformed Church did not participate, it is only that no names of representatives from the Church appears in the programme or events from 1939.

The next point on the agenda of the Central Committee from 1939 was the building of the Huguenot Monument. On 24 October 1940 it was decided that the Monument will stand in Franschhoek. Designs were asked and from the six received, preference was given to the design of Mr. J C Jongens a Dutch architect from Cape Town. The overall design was acceptable but the central group of Huguenot figures, a man women and child in historical clothes, did not satisfy. Again designs for the central group of figures were asked. A sculpture from Pretoria, Coert Steynberg's design was eventually accepted - the figure of a women standing on top of the world. The figure, together with the pond in front of the monument, three high arches behind her and the colonnade at the back forms the very well known and worthy Huguenot Monument of South Africa. The Huguenot Monument at Franschhoek in a very special way symbolizes the origins, settlement and influence of the Huguenots of South Africa. "With its simplicity and graceful lines the monument has a French historical character. The figure of a woman with a bible in her right hand and a broken chain in her left hand personifies the spirit of religious freedom. The French lily (fleur-de-lis) on her dress is a sign of her nobility of character and spirit. She throws off the cloak of oppression to stand in freedom of spirit above the earth. Her eyes are fixed on a vision of the great things to come. At the depicted southern tip of Africa, to which the Huguenots came in small and unsteady ships, appears the symbols of their religion - the Bible; art and culture - a harp; agriculture and viticulture - an sheaf of wheat and a vine; and industry - a spinning wheel. The three impeccable arches symbolize the Trinity. Above them shines the sun of Righteousness and above that is the cross as the symbol of the Christian religion. In the pool with its reflection and in the colonnade in the background is found the spiritual bliss and peace of mind won after much struggle and turbulence. ${ }^{66}$

Apart from the words right at the end of booklet Die Hugenote Monument op Franschhoek under a photo of the Women standing on top of the world, which reads

"Her beauty is an image of the whole history of our people and everything that is noble in ${ }^{i t}$ "67 there is no other reference regarding the Monument to "our people" or the "Afrikaner people." In the Huguenot Monument and the description given, we find back the values of faith and religious freedom and freedom of conscience that we read of in the early documents about and from the French Refugees. We see the symbols of their religion, their labour, the arts and crafts that they brought to South Africa and peace that they found here. The Huguenot Monument in Franschhoek transcends national and international boundaries in its emphasis on the real values that came from the Huguenots. One cannot help but seeing in it the fulfilment of the vision that Sir Henry de Villiers had in 1885 when he

66 Die Hugenote-Monument op Franschhoek. Gedenkskrif uitgegee deur die Hugenote-Gedenkfeeskomitee en opgetstel deur Prof Dr E C Pienaar, voorsitter, ter geleentheid van die plegtige inwyding van die Hugenote-mnument te Franschhoek, op Saterdag 17 April 1948. p 13-16. P Coertzen, The Huguenots of South Africa,150. Die Beheerraad van die Hugenote-Monument, 1948: Die Simboliese betekenis van die Hugenote-Monument te Franschhoek; Korrespondensie van die Hugenote-Vereniging; Die Hugenote Monument Franschhoek, Die Monument van ons Geloofsbelydenis.

67 Die Hugenote-Monument op Franschhoek. Gedenkskrif uitgegee deur die Hugenote-Gedenkfeeskomitee en opgetstel deur Prof Dr E C Pienaar, voorsitter, ter geleentheid van die plegtige inwyding van die Hugenote-mnument te Franschhoek, op Saterdag 17 April 1948. p 24. 
claimed that a Huguenot memorial "must be something that will attract attention, not create an image of smallness, exhibit true art qualities and be so designed that through its allegorical image in marble or whatever material, it will truly recall to mind the great event. ${ }^{68}$ The Monument was inaugurated on 17 April 1948, a date as near as possible to the arrival of the first Huguenots in 1688. On the programme for that occasion we find amongst the names of members of the Central Committee also the names of the local minister of Franschhoek and well as the name of the moderator of the Synod of the Dutch Reformed Church in South Africa Dr A J van der Merwe. ${ }^{69}$

On 21 March 1953 the Huguenot Society of South Africa was founded. The aim of the Society at the time was the maintenance and development of the Protestant tradition, virtues and ideals of the Huguenots as part "of our nation's life" (ons volkslewe). The Society saw as it's task the organising of Huguenot commemorations, to collect and keep Huguenot pieces, to finish the Huguenot register from 1939, to research the Huguenot history and to build relations with Huguenot Societies abroad. ${ }^{70}$ Under the guidance of the Huguenot Society the Huguenot Memorial Museum was erected on land adjacent to the Huguenot Monument. The reconstructed Saasveld building designed by the architect Louis Michel Thibault was opened in Franschhoek as the Huguenot Memorial Museum on Saturday 11 March 1967 by the then State president Mr C R Swart. At the occasion messages were read by Mrs M André Bertrand and $M$ Jacques Allier representatives from the Huguenot Society of France and Baron Lewe van Aduard the Dutch Ambassador to South Africa. ${ }^{71}$ The Museum is the place where pieces of the South African Huguenot heritage are kept and exhibited. There are not many pieces from the original settlers. It is claimed that there is a family bible from the Joubert family; a personal bible of Susanne Gardiol, a snuffbox of Jacques Theron and a writing desk of Jean Blignault. Most of the exhibits are from the descendants of the original Refugees which came after a call from the Huguenot Society to descendants of the Huguenots. Even today exhibition pieces are received form descendants from time to time. Quite a few exhibits and exhibitions have been brought to Franschhoek from Europe. The Museum also received quite a few exhibits from the Huguenot Museum in the Paarl. Today the Museum also houses exhibits form the history of Franschhoek as well as exhibits on the indigenous tribes of the valley.

\section{TERCENTENARY COMMEMORATIONS 1988}

By 1988 it was as if the whole country was in a state of political expectancy. Significant of this whole atmosphere is the fact that about 18 months after the tercentenary Huguenot commemorations the white voters of the country were asked by the government under the leadership of Mr F W de Klerk, a Huguenot descendant, to vote on 6 September 1989 on six matters as a mandate for the government namely to : normalise the political process in South Africa ; move away from racial discrimination ; negotiate a new constitutional dispensation for the country ; advance economical efficiency ; maintain law and order and to remove the distrust between the different communities of South Africa and in- stead build bridges between them. This was the last ballot in South Africa in which whites alone had the vote ${ }^{72}$. The majority of white voters gave the mandates that were asked, indicating that they no longer saw apartheid

68 Henn, MMT, 1984, De Gedenkschool der Hugenoten in Kultuur-Historiese Perspektief. In: Huguenot

Society of South Africa, Bulletin 22, 1984-1985. p 24.

69 Feesprogram vir die Plegtige Inwyding van die Hugenote Monument. Franschhoek 17 April 1948.

70 Documents of the Huguenot Society of South Africa, Huguenot Memorial Museum, Franschhoek.

71 Huguenot Memorial Museum. Booklet, s.a.

72 FW de Klerk, Die Laaste Trek - 'n Nuwe Begin. Die Outobiografie. Human en Rousseau. Kaapstad,

Pretoria, Johannesburg. 1999. p165-166. 
as the answer to the questions and problems confronting the country in fact indicating that apartheid was morally not justifiable and that they wanted to move into a new democratic dispensation in which the rights of all the citizens, also the right to religious freedom, would be guaranteed. It was in this political atmosphere that the tercentenary commemorations of the Huguenots took place and must be understood.

Already in 1981 the Huguenot Society started the planning. It was a national commemoration due to the fact that it was subsidised by the government. Furthermore it was a ProtestantReformational oriented celebration in the context of history and due to the association with the faith struggle of the Huguenots. Aims that were set for the commemoration included a Huguenot cantate; a libretto with the theme persecution, flight and settlement; a competition for the best drama; compositions for smaller choirs; an epic poem; a commemoration book; a festival brochure; a festival logo - "Le Festival des Huguenots"; souvenirs; tablo's; art exhibitions; cultural festivals and family reunions. It was important for the organisers that the festival have a benevolent character meaning that it must build local and international relations and inspire and motivate people to keep and enhance those values that transcend time and to also pass it on to other culture groups as well. The national character of the commemoration meant that it will be open to all population groups of South Africa especially for those who associated with it willingly. Thousands of spectators participated and associated with the festival. Members form the Board of Deputies of the Coloured people were especially invited to attend highlights on the programme. On 5 August $1987 \mathrm{Mr}$ Arends form the Administration office of the Board of Deputies sent out a circular to all primary and secondary schools in Athlone, Bellville, Mitchell's plain, Paarl and Wynberg encouraging the pupils to participate in the main festival in Table Bay, the Paarl and Franschhoek. ${ }^{73}$

On 3 August 1983 a Central Committee was appointed under the Chairmanship of Mr Gene Louw the Administrator of the Cape Province. On the Committee were representatives from the Dutch Reformed Church, the Reformed Churches in South Africa, the Netherlands Reformed Church in Africa, and the Presbyterian Church. The Apostolic Faith Mission was also asked to appoint a representative. Furthermore there were representatives from the Provincial Administrations of the Cape, Transvaal, and the Orange Free State. Due to lack of permission for funding the province of Natal was not represented. The following cultural organisations were also represented: The FAK (Federation of Afrikaans Cultural Organisations) and the Academy for Science and Art. The South African Broadcasting Association was also asked to appoint a representative. $^{74}$

In a letter after the Festival the chairperson Mr Louw wrote to the Minister of Education and Culture stating that the festival was very successful and than thousands upon thousands of people were involved. It bound people together as well as past and future. It gave light for the future, encouraged, inspired and motivated people to adhere and continue to keep to those Christian civilisation values which transcends the time. This message was also communicated to other culture groups in the country.

The festival also succeeded in building local and international relationships. On the basis of free association quite a few visitors from Western countries also attended the festivities. The youth of South Africa and other people involved in the programmes succeeded in bringing both a merry and a sanctified atmosphere to the festival. ${ }^{75}$

The Huguenot Commemoration Festival of 1988 was unique in that for the first time in the

73 NP Badenhorst, Le Festival des Huguenots 300. Verslag Hugenote Fees 1988, p 53-57

74 NP Badenhorst, Le Festival des Huguenots 300. Verslag Hugenote Fees 1988, p 57-60

75 Letter form Mr Eugene Louw, Administrator of the Cape Province to Minister P J Clase, Minister of

Education and Culture. In: NP Badenhorst, Le Festival des Huguenots 300. Verslag Hugenote Fees 1988. 
history of Huguenot commemorations in SA it was a national commemoration. The organisers tried to involve as many population groups and Christian denominations as possible, it was not a festival for only a select group from society. Throughout it was a festival of religious thanksgiving for the Huguenot heritage in South Africa while at the same time people were inspired to cultivate and keep the values that the Huguenots represented.

\section{CONCLUSION}

In what went before, we heard of the early French refugees that came to South Africa and how important freedom of religion and the right to freedom of conscience were for them. For them these were the most precious things on earth. In the documents the refugees are described as people with courage, guts and love of freedom. That is the essential heritage that they brought to South Africa.

The story of Huguenot identity in South Africa tells us of a people who in time lost their French identity and church and who completely united with the Dutch population and the Dutch Reformed Church. From the union of the French and the Dutch a new identity - that of the Afrikaner people - started to develop and often it was very difficult to keep the memory of the Huguenots in South Africa and the promotion of the Afrikaans language and culture and Afrikaner nationalism apart.

It is very conspicuous that throughout the and nineteenth century when the commemoration of the Huguenots started, it was most of the time linked to schools and education. Education was the plight of the people i.e. the Dutch and the French or what they became during those the times - the Afrikaners. In lack of very few matters that could be commemorated to address this urgent need in South Africa it seems that the commemorations of the Huguenots were extensively used in this regard.

The story of the Huguenot commemorations is often also the story of infighting between communities about who could participate in Huguenot commemorations and where the best place for a Huguenot memorial would be; the Paarl, Wellington, Franschhoek, Simondium or Cape Town?

Through the years we see that the Huguenots and the commemoration of them were often not only about the heritage of the original Refugees but it was often used for other purposes too like education (Simondium, The Huguenot Seminary in Wellington, The Gedenkschool der Hugenoten); mission to the Africa (The Huguenot Seminary in Wellington); Afrikaner nationalism (De Gedenkschool der Hugenote); "our church" (De Kerkbode 1885); the Afrikaner people (1939 and 1948) and of late for the reconstruction of their history and the history of South Africa. The Huguenot Monument with its beautiful allegorical image succeeded in a unique way to transcend all the secondary causes to become and image of and a call to the universal values of freedom of religion and freedom of conscience.

The commemoration of the Huguenots always called for items from the original Huguenots to be donated so that it could be kept in a memorial. Most of the time hardly anything came of these calls, simply because there was none or very few heritage pieces that could be donated and kept. Much of what was donated came from later descendants of the Huguenots.

Throughout the efforts to commemorate the Huguenots we always find the call to compile a list or a register of the Huguenots that came to South Africa. From some of these effort nothing came about while others were more successful. Today there is a very live interest in Huguenot genealogy and quite a few genealogies of Huguenot families have been compiled and are available at the Huguenot Memorial Museum. The Huguenot Society of South Africa has also recently started with a very successful programme to publish Huguenot genealogies. The 
interest in their Huguenot roots by different communities in South Africa is only something that can be appreciated and encouraged.

Often in the commemorations there is a tendency to idealize the Huguenots. They were such noble people of noble blood; they were the best settlers that ever came to South Africa. And yet, in spite of all the romanticizing of the Huguenot heritage it is encouraging to see how increasingly the true heritage of the Huguenots, namely freedom of religion and freedom of conscience are seen as the values that prevail in spite of the fact that there is often historical evidence that also shows another, less romantic side of the Huguenots.

There was a time form about 1885 to 1998 that the Dutch Reformed Church was involved and also guards over the Huguenot heritage of South Africa and inspired many people also in outlaying districts and other provinces. During those years it was in fact nearly only the Church that had and kept a Huguenot Memorial - it synodical buildings. It is sad that after 1994, in the New South Africa, the Church apparently let go of this guardianship.

In 1994 South Africa became a full democracy for all its inhabitants. For the first time in its history the Constitution read in article 15(1) "Everyone has the right to freedom of conscience, religion, thought, belief and opinion." ${ }^{\prime 76}$ What was granted to the Huguenots in 1688 now became a Constitutional protected right of every citizen of the country. The Huguenot Monument in Franschoek with its message of religious freedom and freedom of conscience now is not only a true monument for the Huguenots but an inspiration for all the people of South Africa.

In 2003 Philip Denis asked for a more critical appraisal of the role of the Huguenots in South African history to replace "the myth about the Huguenots" created by the Afrikaners to strengthen their own identity". When we look at the memory of the Huguenots in South Africa we read about the values that were really important to them. In the commemorations they were used and claimed for many causes: education, mission, Afrikaner nationalism, sectional interests and as an apology for the "New South Africa". The Dutch Reformed Church also claimed them for its cause. But throughout history there were always the underlying values of freedom of conscience and freedom of religion - terms which they themselves used to identify themselves. These values which transcend all other interests and uses, find clear expression in the Huguenot Monument and they make that the Monument and what it stands for, is a valuable asset for all the peoples, cultures, languages and faiths of South Africa.

\section{KEY WORDS}

Huguenots

French Refugees

Freedom of religion

Freedom of conscience

Allegorical image

Commemorations

\section{TREFWOORDE}

Hugenote

Franse Vlugtelinge

Godsdiensvryheid

Vryheid van gewete

Allegoriese beeld

Herdenkings 